\title{
Contamination of arsenic and heavy metals in coal exploitation area
}

\author{
R. Sharma ${ }^{1}$, A. Yadav ${ }^{1}$, S. Ramteke ${ }^{1}$, S. Chakradhari ${ }^{1}$, K.S. Patel ${ }^{1}$, \\ L. Lata ${ }^{2}$, H. Milosh ${ }^{2}$, P. Li ${ }^{3}$, J. Allen ${ }^{3} \&$ W. Corns ${ }^{3}$ \\ ${ }^{1}$ School of Studies in Chemistry/Environmental Science, \\ Pt. Ravishankar Shukla University, Raipur, India \\ ${ }^{2}$ Department of Soil Science/Geology, Maria Curie-Sktodowska University, \\ Lublin, Poland \\ ${ }^{3}$ PS Analytical Ltd, Arthur House, Orpington, Kent, UK
}

\begin{abstract}
The coal is a dirty fuel, containing As and other heavy metals (HMs) at the trace levels. Several millions tons of coals are exploited in the Korba basin, CG, India to generate electricity. In this work, distribution of As and other $\mathrm{HMs}$ i.e. $\mathrm{Cr}, \mathrm{Mn}, \mathrm{Fe}, \mathrm{Ni}, \mathrm{Cu}, \mathrm{Zn}, \mathrm{Cd}, \mathrm{Pb}$ and $\mathrm{Hg}$ in the surface soil and sediment are described. Three metals i.e. Mn, Fe and Ni occurred at higher concentrations, ranging $(n=30)$ from $2.3-6.4,0.08-0.22$ and 0.04 $0.16 \%$ with mean value $(\mathrm{p}=0.05)$ of $4.3 \pm 0.4,0.14 \pm 0.02$ and $0.08 \pm 0.01 \%$, respectively. The concentration of elements i.e. As, $\mathrm{Cr}, \mathrm{Cu}, \mathrm{Zn}, \mathrm{Cd}, \mathrm{Pb}$ and $\mathrm{Hg}$ in the soil was ranged $(\mathrm{n}=30)$ from 49-164, 30-78, 44-131, $87-220,0.11-0.56,72-194$ and $0.11-0.39 \mathrm{mg} \mathrm{kg}^{-1}$ with mean value $(\mathrm{p}=0.05)$ of $(\mathrm{p}=0.05) 106 \pm 11,51 \pm 5$, $86 \pm 8,156 \pm 10,0.33 \pm 0.04,130 \pm 10$ and $0.22 \pm 0.03 \mathrm{mg} \mathrm{kg}^{-1}$, respectively. The concentration of the As in the sediments $(\mathrm{n}=26)$ was ranged from $36-154 \mathrm{mg} \mathrm{kg}^{-1}$ with mean value of $93 \pm 12 \mathrm{mg} \mathrm{kg}^{-1}$. The toxic inorganic $\mathrm{As}(\mathrm{III})$ and $\mathrm{As}(\mathrm{V})$ species are found to exist in the soil and sediment. The concentration variations, pollution indices and sources of the contaminants in the geomedia are discussed.
\end{abstract}

\section{INTRODUCTION}

Pollution of urban geomedia is of a great public health interest due to receiving of large amounts of pollutants from multiple sources including industrial wastes, vehicle emissions, coal and biomass burnings, etc. (Li et al., 2012; Obaidy et al., 2013; Plyaskina \& Ladonin, 2009). India is the third-largest producer of coal in the world. Coal is a naturally occurring combustible material contains elemental carbon, sulfur, hydrocarbons, trace metals, etc. (Chou, 2012). Several environmental issues i.e. acid mine drainage, deposition of toxic compounds, environmental pollution, halting of acid rain, health hazards, storage of solid waste, etc. were observed due to coal burnings (Agrawal et al., 2010; Bhuiyan et al., 2010; Guttikunda et al., 2014; Pandey et al., 2011; Sengupta et al., 2010; Sheoran et al., 2011; Singh et al., 2010).

Several millions tons of coal is mined out and burnt in the Korba basin for generation of electricity by pouring the effluents into the environment. The whole environment is covered by the fly ash and black carbon $(\mathrm{BC})$. The rain and groundwater are acidic with high content of metals and fluoride Patel et al., 2001; 2016). The HMs contamination of the Korba basin has not been carried out so far. Hence, in this work, the contamination of surface soil and sediment of the Korba basin with elements i.e. $\mathrm{BC}, \mathrm{As}, \mathrm{Fe}, \mathrm{Cr}, \mathrm{Mn}, \mathrm{Ni}, \mathrm{Cu}$,
$\mathrm{Zn}, \mathrm{Cd}, \mathrm{Pb}$ and $\mathrm{Hg}$ is described. The concentration variations, enrichments and sources of the metals in the soil and sediment are discussed.

\section{METHODS AND EXPERIMENTAL}

\subsection{Study area and sampling}

Korba coalfield $\left(22.35^{\circ} \mathrm{N}\right.$ and $\left.82.68^{\circ} \mathrm{E}\right)$ is located in the Chhattisgarh state, India in the basin of the Hasdeo river, extending over $\approx 530 \mathrm{~km}^{2}$. The population of Korba area is $\approx 1.0$ million. Several coal mines are in operation with annual production of $\approx 3 \mathrm{BT}$ coal annually since year 1960 . A huge amount of coal

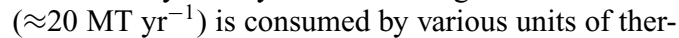
mal power plants to produce $6000 \mathrm{MW}$ electricity with emission of $\approx 6 \mathrm{MT}$ ash into the environment. The Asia biggest aluminum plant $\left(3.2 \times 10^{5} \mathrm{TPY}\right.$ Aluminum smelter) is also in the operation in the Korba area.

The soil and sediment samples were collected from 30 and 26 locations of Korba area lie over $\approx 500 \mathrm{~km}^{2}$ areas (Fig. 1). One kilogram of sample from each site $(0-10 \mathrm{~cm})$ was collected in a clean polyethylene container during January, 2011-2017 as prescribed in the literature (Tan, 2005). For depth profile studies, the soil samples were collected at depth of 0-10, 11-20 and $21-30 \mathrm{~cm}$. 


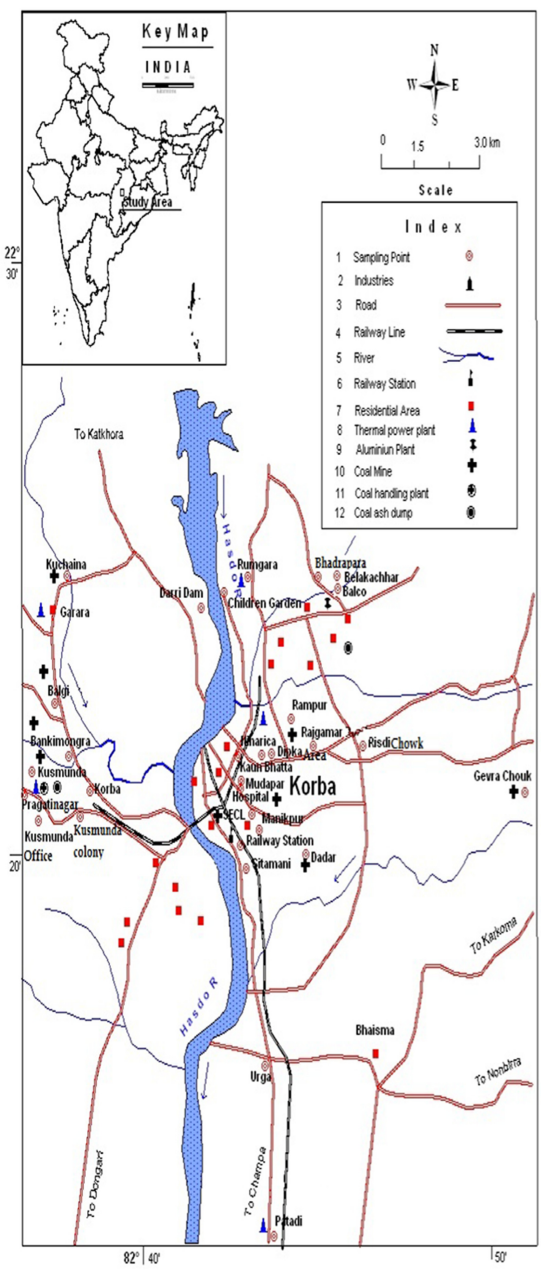

Figure 1. Representation of sampling locations in Korba basin.

\subsection{Analysis}

The soil samples were dried, milled and particles of $\leq 1 \mathrm{~mm}$ were sieved out. A $10 \mathrm{~g}$ sample with $20 \mathrm{~mL}$ deionized water in a $100-\mathrm{mL}$ conical flask was agitated in an ultrasonic bath for $6 \mathrm{~h}$. The $\mathrm{pH}$ values of the extract were measured by the Hanna $\mathrm{pH}$ meter typeHI991300.

The weighed amount of soil sample $(0.25 \mathrm{~g})$ was digested with acids $\left(3 \mathrm{~mL} \mathrm{HCl}\right.$ and $\left.1 \mathrm{~mL} \mathrm{HNO}_{3}\right)$ in closed system with P/T MARS CEM (Varian Company) microwave oven. The acid extract was used for monitoring of the elements.

The CHNSO-IRMS Analyzer, SV Instruments Analytica Pvt. Ltd. was used for analysis of the black or elemental carbon (BC or EC). The total carbon (TC) in the soil sample was oxidized at $1020^{\circ} \mathrm{C}$ with $\mathrm{O}_{2}$ into $\mathrm{CO}_{2}$ with constant helium flow.

The analytical techniques i.e. Varian ICP-OES-700ES, GF-AAS SpectrAA 220 and CV-AAS SpectrAA $55 \mathrm{~B}$ were used for monitoring of metals i.e. $\mathrm{Cr}, \mathrm{Mn}$,
$\mathrm{Fe}, \mathrm{Ni}, \mathrm{Cu}, \mathrm{Zn}$ and $\mathrm{Pb}$; $\mathrm{As}$ and $\mathrm{Cd}$; and $\mathrm{Hg}$ in the soil extract, respectively. The standard soil sample (NCS DC 73382 CRM) was used for the quality control.

A $0.2 \mathrm{~g}$ of sediment sample was taken into a $10-\mathrm{mL}$ Teflon centrifuge tube by subsequent addition of $5 \mathrm{~mL}$ of $0.5 \mathrm{M} \mathrm{H}_{3} \mathrm{PO}_{4}$ and kept overnight. A $2 \mathrm{~mL}$ of filtered solution was diluted to $10 \mathrm{~mL}$ with sodium phosphate to use as HPLC mobile phase. The As-species (i.e. As(III), As(V), MMA and DMA) were quantified by using the technique i.e. HPLC-AFS

The pollution indices i.e. enrichment factor (EF), contamination factor (CF) and pollution load index (PLI) are used to determine element contents in the soil samples with respect to the base line concentration. These relate the concentration of an element, X, to a crustal element (e.g. Al) in the soil sample, and this ratio is then normalized to the ratio of those elements in the earth's crust. The following equations were used for the calculation of the pollution indices (Sinex \& Helz, 1981; Tomlinson et al., 1980):

$$
\begin{aligned}
& \mathrm{EF}=\left\{\left[\mathrm{X}_{\mathrm{s}}\right] /\left[\mathrm{Al}_{\mathrm{s}}\right]\right\} /\left\{\left[\mathrm{X}_{\mathrm{e}}\right] /\left[\mathrm{Al}_{\mathrm{e}}\right]\right\} \\
& \mathrm{CF}=\left\{\left[\mathrm{X}_{\mathrm{s}}\right] /\left[\mathrm{X}_{\mathrm{e}}\right]\right\} \\
& \mathrm{PLI}=\left(\mathrm{CF}_{1} \times \mathrm{CF}_{2} \times \mathrm{CF}_{3} \times \mathrm{CF}_{4} \ldots \ldots \ldots \mathrm{CF}_{\mathrm{n}}\right)^{l / n}
\end{aligned}
$$

where, symbols: $\mathrm{X}_{\mathrm{s}}, \mathrm{X}_{\mathrm{e}}, \mathrm{Al}_{\mathrm{s}}$ and $\mathrm{Al}_{\mathrm{e}}$ denote concentration of metal and $\mathrm{Al}$ in the soil and earth crust, respectively.

The IBM SPSS Statistics 23 software was used for the preparation of the dendrogram.

\section{RESULTS AND DISCUSSION}

\section{1 pH of extract}

The soil and sediment were colored, ranging from brown to blackish. The $\mathrm{pH}$ values of the soil and sediment extracts $(\mathrm{n}=30)$ ranged from 5.4-7.5 and from 5.4-8.1 with mean value $(p=0.05)$ of $6.6 \pm 0.2$ and $6.6 \pm 0.3$, respectively. The extracts were observed to be slightly acidic, may be due to high chloride and sulfate contents. The lowest $\mathrm{pH}$ value was seen in the Korba city, may be due to the high anthropogenic activities.

\subsection{Distribution of black carbon}

The BC concentration in the soil and sediment was ranged from 3.4-7.9 and 3.6-14.0\% with mean value $(\mathrm{p}=0.05)$ of $5.6 \pm 0.4$ and $9.2 \pm 1.0 \%$, respectively. The higher loading of the $\mathrm{BC}$ in the sediment samples was observed, may be due to its transport by the runoff water. The BC content in the geomedia of the studied area was found to be higher than reported in other regions, probably due to huge coal burning (Han et al., 2009; He \& Zhang, 2009; Muri et al., 2002).

\subsection{Distribution of elements}

The metals i.e. $\mathrm{Mn}, \mathrm{Fe}$ and $\mathrm{Ni}$ occurred in the soil of Korba basin at high levels, ranging $(\mathrm{n}=30)$ from $2.3-6.4,0.08-0.22$ and $0.04-0.16 \%$ with mean value $(p=0.05)$ of $4.3 \pm 0.4,0.14 \pm 0.02$ and $0.08 \pm 0.01 \%$, respectively. The concentration 
Table 1. Distribution of major metals in soil, $\mathrm{mg} \mathrm{kg}^{-1}$.

\begin{tabular}{|c|c|c|c|c|c|}
\hline S. No. & Location & As & $\mathrm{Cd}$ & $\mathrm{Pb}$ & $\mathrm{Hg}$ \\
\hline 1 & Niharica & 146 & 0.47 & 163 & 0.21 \\
\hline 2 & Kuan Bhatta & 80 & 0.26 & 119 & 0.18 \\
\hline 3 & Railway Station & 78 & 0.11 & 95 & 0.11 \\
\hline 4 & Sitamani & 140 & 0.43 & 126 & 0.23 \\
\hline 5 & Rajgamar & 164 & 0.56 & 189 & 0.39 \\
\hline 6 & Rumgara & 60 & 0.21 & 126 & 0.24 \\
\hline 7 & Darri dam & 96 & 0.27 & 116 & 0.19 \\
\hline 8 & Chaildren Garden & 61 & 0.35 & 116 & 0.20 \\
\hline 9 & Dipka-I & 61 & 0.27 & 117 & 0.14 \\
\hline 10 & Dipika-II & 49 & 0.21 & 137 & 0.23 \\
\hline 11 & Gevera Chowk & 102 & 0.31 & 114 & 0.22 \\
\hline 12 & Kusmunda-I & 96 & 0.17 & 127 & 0.21 \\
\hline 13 & Kusmunda-II & 106 & 0.29 & 126 & 0.25 \\
\hline 14 & Kusmunada-III & 130 & 0.41 & 154 & 0.25 \\
\hline 15 & Korba & 145 & 0.54 & 190 & 0.37 \\
\hline 16 & Banki mongra & 120 & 0.21 & 110 & 0.26 \\
\hline 17 & Balgi & 111 & 0.38 & 88 & 0.25 \\
\hline 18 & Kuchaina & 97 & 0.25 & 72 & 0.13 \\
\hline 19 & Balco & 134 & 0.44 & 168 & 0.22 \\
\hline 20 & bhadrapara & 86 & 0.33 & 106 & 0.11 \\
\hline 21 & Risdi Chowk & 83 & 0.34 & 102 & 0.13 \\
\hline 22 & Manikpur & 79 & 0.30 & 96 & 0.15 \\
\hline 23 & Dadar & 94 & 0.39 & 138 & 0.24 \\
\hline 24 & SECL & 98 & 0.41 & 140 & 0.21 \\
\hline 25 & Mudapar & 105 & 0.38 & 119 & 0.24 \\
\hline 26 & Rampur, PWD & 101 & 0.32 & 125 & 0.22 \\
\hline 27 & SECL Hospital & 149 & 0.49 & 160 & 0.31 \\
\hline 28 & Belakachar & 131 & 0.29 & 149 & 0.30 \\
\hline 29 & Urga & 134 & 0.21 & 129 & 0.26 \\
\hline 30 & Patadi & 163 & 0.48 & 194 & 0.38 \\
\hline
\end{tabular}

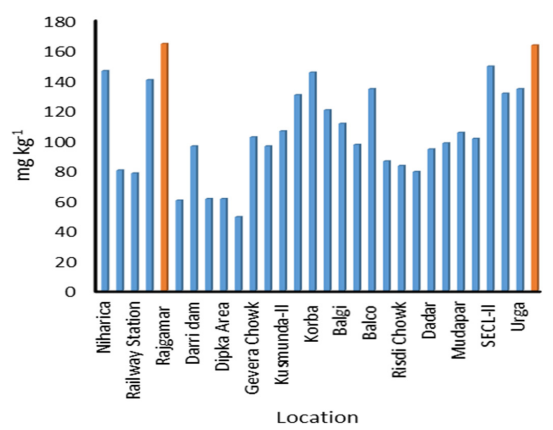

Figure 2. Distribution of As in surface soil.

of elements i.e. As, $\mathrm{Cr}, \mathrm{Cu}, \mathrm{Zn}, \mathrm{Cd}, \mathrm{Pb}$ and $\mathrm{Hg}$ ranged $(n=30)$ from 49-164, 30-78, 44-131, 87-220, $0.11-0.56,72-194$ and $0.11-0.39 \mathrm{mg} \mathrm{kg}^{-1}$ with mean value $(\mathrm{p}=0.05)$ of $106 \pm 11,51 \pm 5,86 \pm 8,156 \pm 10$ $0.33 \pm 0.04, \quad 130 \pm 10$ and $0.22 \pm 0.03 \mathrm{mg} \mathrm{kg}^{-1}$, respectively (Table 1).

The concentration of elements i.e. As, $\mathrm{Cr}, \mathrm{Cu}$, $\mathrm{Zn}, \mathrm{Cd}, \mathrm{Pb}$ and $\mathrm{Hg}$ in the sediments ranged from 36-154, 29-7, 18-92, 42-294, 0.14-1.19, 26-127 and $0.12-0.82 \mathrm{mg} \mathrm{kg}^{-1}$ with mean value of $93 \pm 12$, $49 \pm 5,49 \pm 8,142 \pm 28,0.59 \pm 0.11,72 \pm 13$ and $0.44 \pm 0.08 \mathrm{mg} \mathrm{kg}^{-1}$, respectively (Table 2 ). The lower concentration of the elements (except $\mathrm{Cd}$ and $\mathrm{Hg}$ ) in the sediment than the soil was observed.
Table 2. Distribution of heavy metals in sediments.

\begin{tabular}{llrlrl}
\hline S. No. & Location & As & Cd & $\mathrm{Pb}$ & $\mathrm{Hg}$ \\
\hline 1 & Shakti Nagar & 63 & 0.14 & 33 & 0.16 \\
2 & Gevra, Dipka & 96 & 0.24 & 37 & 0.17 \\
3 & PN, Dipka & 98 & 0.27 & 49 & 0.23 \\
4 & Banki, Dipka & 36 & 0.52 & 47 & 0.25 \\
5 & Delwadih & 100 & 0.63 & 81 & 0.31 \\
6 & Shingali & 82 & 0.36 & 78 & 0.28 \\
7 & Kusmunda & 92 & 0.50 & 92 & 0.36 \\
8 & Rajgamar-3 & 65 & 0.45 & 74 & 0.26 \\
9 & Mudapar & 114 & 0.65 & 35 & 0.21 \\
10 & PN, Darri & 138 & 0.82 & 106 & 0.61 \\
11 & Darri west & 127 & 0.95 & 127 & 0.77 \\
12 & Jamnipali & 154 & 1.19 & 82 & 0.63 \\
13 & Gopalpur & 149 & 1.18 & 120 & 0.82 \\
14 & HTPP, Darri & 111 & 0.84 & 112 & 0.74 \\
15 & Manuikpur-1 & 127 & 0.77 & 107 & 0.63 \\
16 & Manikpur-2 & 51 & 0.39 & 31 & 0.30 \\
17 & Dader-1 & 79 & 0.66 & 54 & 0.54 \\
18 & Dader-2 & 99 & 0.72 & 87 & 0.65 \\
19 & Kudarikhar & 43 & 0.42 & 37 & 0.33 \\
20 & Naktikhar & 93 & 0.64 & 75 & 0.53 \\
21 & Danras-1 & 98 & 0.62 & 53 & 0.46 \\
22 & Danras-2 & 41 & 0.20 & 26 & 0.12 \\
23 & SN-Balco & 47 & 0.22 & 48 & 0.32 \\
24 & Pathadi & 79 & 0.96 & 125 & 0.71 \\
25 & Dhendheni & 69 & 0.62 & 108 & 0.61 \\
26 & Sukhri & 30 & 0.35 & 35 & 0.31 \\
\hline & & & & &
\end{tabular}

They occurred in the following increasing order: $\mathrm{Hg}<\mathrm{Cd}<\mathrm{Cr}<\mathrm{Cu}<\mathrm{As}<\mathrm{Pb}<\mathrm{Zn}<\mathrm{Ni}<\mathrm{Mn}<\mathrm{Fe}$ in the soil. The highest concentration of As was seen near the point sources i.e. thermal power plant, coal mine, urban area, etc. as shown in Figure 2. The concentration of As in the geomedia of studied area was several folds $(>10)$ higher than permissible limit of $5 \mathrm{mg} \mathrm{kg}^{-1}$. The concentration of the As and heavy metals in the soil and sediment of the Korba basin was higher than values reported in other region of the country and world, probably due to huge coal mining and burning (Dahal et al., 2008; Ilwon et al., 2003; Kwon et al., 2017; Muller, 1969; Sheela et al., 2012; Rudnick \& Gao, 2003; Shrivastava et al., 2014; Whitmore et al., 2008).

\subsection{Vertical distribution of elements}

The concentration of elements (i.e. As, $\mathrm{Cr}, \mathrm{Ni}, \mathrm{Cu}$, $\mathrm{Zn}, \mathrm{Cd}$ and $\mathrm{Hg}$ ) was increased as the depth profile was increased up to $30 \mathrm{~cm}$ unlikely to $\mathrm{Mn}, \mathrm{Fe}$ and $\mathrm{Pb}$, may be due to their less binding with the organic compounds (Fig. 3).

\subsection{Temporal variation of elements}

The increased temporal variation of As over periods: 2011-2015 was observed due to continuous mining and burning of the coals (Fig. 4). The rate of temporal increase in the As concentration was $\approx 6 \%$ in the geomedia due to continuous coal burning. At least $15 \%$ higher concentration of the As in the soil with respect 


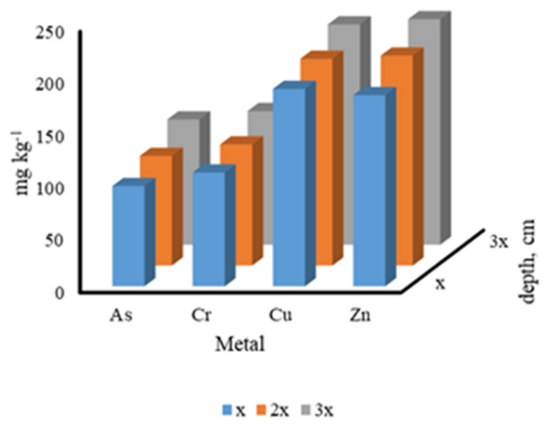

Figure 3. Verticle distribution of As and other metals in soil, $\mathrm{x}=0-10,2 \mathrm{x}=10-20,3 \mathrm{x}=20-30 \mathrm{~cm}$.

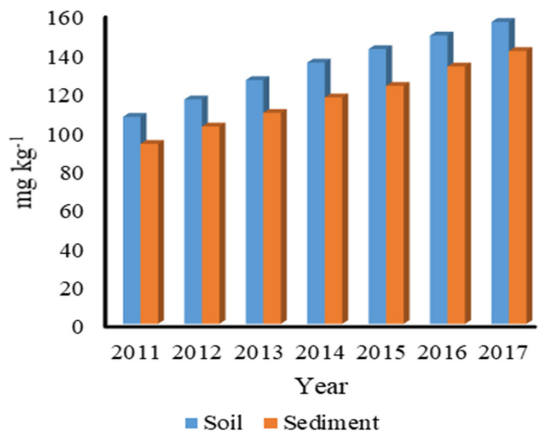

Figure 4. Temporal variation of As in soil and sediment.

Table 3. Speciation of arsenic in sediments, $\mathrm{mg} \mathrm{kg}^{-1}$.

\begin{tabular}{llllccc}
\hline S. No. & As(III) & DMA & MMA & As(V) & AsT & EE, \% \\
\hline S1 & 1.08 & - & - & 14.0 & 15.08 & 27.1 \\
S2 & - & - & - & 9.08 & 9.08 & 110.7 \\
SE1 & 0.1 & - & - & 2.10 & 2.20 & 73.3 \\
SE2 & 0.15 & - & - & 6.0 & 6.15 & 130.8 \\
SD3 & - & - & - & 2.40 & 2.4 & 75
\end{tabular}

$\mathrm{EE}=$ Extraction efficiency $(100 \%)$

the sediment was observed due to its washout by the aqueous media.

\subsection{Speciation of arsenic}

The As(III), As(V), MMA and DMA were quantified in the soil and sediment extracts by using technique i.e. HPLC-AFS (Table 3). The organic species i.e. MMA and DMA were not detected in the soil and sediment extracts. The whole As in soil and sediment samples of studied area was found in the toxic inorganic forms.

\subsection{Sources}

The correlation coefficient matrix for $\mathrm{BC}$ and nine metals in the soil is presented in Table 4. A fair correlation $(\mathrm{r}=0.58-0.82)$ of the metals with $\mathrm{BC}$ was observed, may be due to deposition by multiple sources
Table 4. Correlation coefficient matrix of elements.

\begin{tabular}{lllllllllll}
\hline & $\mathrm{BC}$ & $\mathrm{Fe}$ & $\mathrm{Ni}$ & $\mathrm{Cr}$ & $\mathrm{Cu}$ & $\mathrm{Zn}$ & $\mathrm{Pb}$ & $\mathrm{Hg}$ & $\mathrm{Cd}$ & $\mathrm{As}$ \\
\hline $\mathrm{BC}$ & 1.00 & & & & & & & & & \\
$\mathrm{Fe}$ & 0.58 & 1.00 & & & & & & & & \\
$\mathrm{Ni}$ & 0.59 & 0.41 & 1.00 & & & & & & & \\
$\mathrm{Cr}$ & 0.70 & 0.55 & 0.39 & 1.00 & & & & & & \\
$\mathrm{Cu}$ & 0.74 & 0.60 & 0.56 & 0.73 & 1.00 & & & & & \\
$\mathrm{Zn}$ & 0.74 & 0.64 & 0.45 & 0.56 & 0.75 & 1.00 & & & & \\
$\mathrm{~Pb}$ & 0.81 & 0.77 & 0.59 & 0.59 & 0.72 & 0.72 & 1.00 & & & \\
$\mathrm{Hg}$ & 0.76 & 0.55 & 0.52 & 0.52 & 0.65 & 0.67 & 0.80 & 1.00 & & \\
$\mathrm{Cd}$ & 0.82 & 0.68 & 0.57 & 0.57 & 0.58 & 0.67 & 0.69 & 0.59 & 1.00 & \\
$\mathrm{As}$ & 0.78 & 0.42 & 0.49 & 0.49 & 0.61 & 0.64 & 0.67 & 0.72 & 0.68 & 1.00 \\
\hline
\end{tabular}

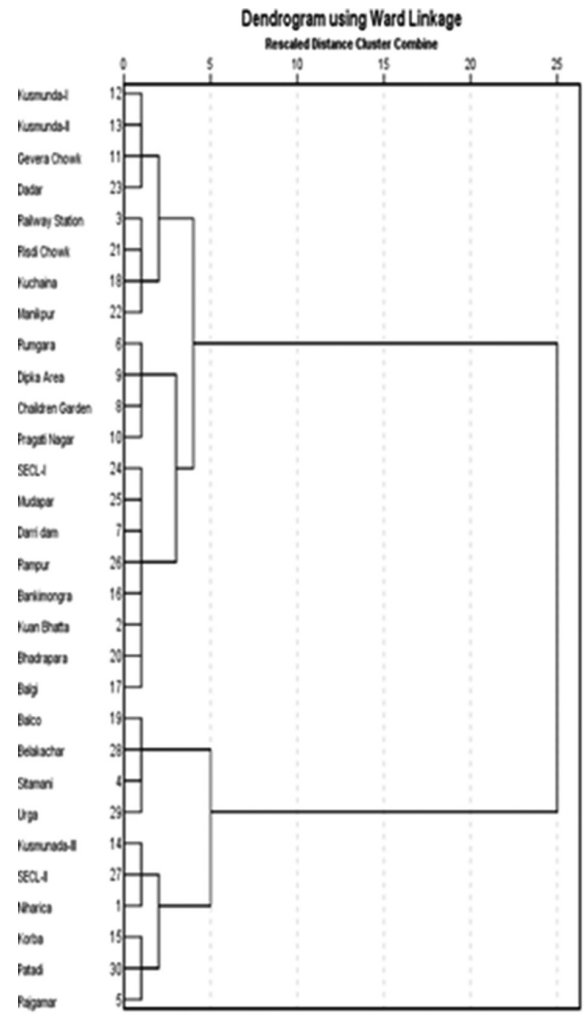

Figure 5. Dendrogram for group linkage of chemical characteristics of locations.

i.e. coal burning, fly ash, alumina roasting, etc. Similarly, fair correlation coefficient (0.39-0.80) among the metals was marked, showing deposition by the multiple sources.

A dendrogram to know linkage between similar groups is plotted, using sum of total concentration of three metals i.e. $\mathrm{As}, \mathrm{Zn}$ and $\mathrm{Pb}$ as discriminating factor. The dendrogram was categorized into two groups: group-I and -II with inclusion of 20 and10 locations as shown in Figure 5. The higher concentration of the $\mathrm{As}+\mathrm{Zn}+\mathrm{Pb}\left(>400 \mathrm{mg} \mathrm{kg}^{-1}\right)$ was seen in group-II, may be due to loading of point sources (i.e. coal mines, aluminum plant and thermal power plant) effluents. 


\subsection{Enrichment}

The background concentration of $\mathrm{Al}, \mathrm{Fe}, \mathrm{Mn}, \mathrm{Cr}$, $\mathrm{Zn}, \mathrm{Ni}, \mathrm{Cu}, \mathrm{Pb}, \mathrm{As}, \mathrm{Cd}$ and $\mathrm{Hg}$ reported was $8.2 \%, 3.9 \%, 775 \mathrm{mg} \mathrm{kg}^{-1}, 92 \mathrm{mg} \mathrm{kg}^{-1}, 67 \mathrm{mg} \mathrm{kg}^{-1}$, $47 \mathrm{mg} \mathrm{kg}^{-1}, 28 \mathrm{mg} \mathrm{kg}^{-1}, 17 \mathrm{mg} \mathrm{kg}^{-1}, 4.8 \mathrm{mg} \mathrm{kg}^{-1}$, $0.09 \mathrm{mg} \mathrm{kg}^{-1}$ and $0.05 \mathrm{mg} \mathrm{kg}^{-1}$, respectively. The elements i.e. $\mathrm{Ni}$ and $\mathrm{As} ; \mathrm{P}, \mathrm{Cd}, \mathrm{Pb}$ and $\mathrm{Hg}$; and $\mathrm{S}$, $\mathrm{Cl}, \mathrm{Mn}, \mathrm{Cu}$ and $\mathrm{Zn}$ were highly $(20 \geq \mathrm{EF}<40)$, significantly $(5 \geq \mathrm{EF}<20)$ and moderately $(2 \geq \mathrm{EF}<5)$ were enriched in the soil, respectively. Similarly, the soil was highly $(\mathrm{CF} \geq 6)$, considerably $(3 \geq \mathrm{CF}<6)$ and moderately $(1 \geq \mathrm{CF}<3)$ contaminated with As, $\mathrm{Ni}$ and $\mathrm{Pb} ; \mathrm{S}, \mathrm{Cl}, \mathrm{P}, \mathrm{Cu}, \mathrm{Cd}$ and $\mathrm{Hg}$ and $\mathrm{Mn}, \mathrm{Fe}$ and $\mathrm{Zn}$, respectively. The PLI value for heavy metals i.e. $\mathrm{As}, \mathrm{Ni}, \mathrm{Pb}, \mathrm{Cd}$ and $\mathrm{Hg}$ was found to be 8.6 indicating their high contamination in the soil.

\section{CONCLUSIONS}

The enormous coal burning tends to increase the concentration of elements i.e. $\mathrm{As}, \mathrm{Zn}, \mathrm{Cd}, \mathrm{Pb}$ and $\mathrm{Hg}$ in the geomedia of the Korba basin. The highest pollution indices for elements i.e. $\mathrm{As}, \mathrm{Ni}$ and $\mathrm{Pb}$ were recorded. The vertical transport of elements i.e. As, $\mathrm{Cr}, \mathrm{Cu}, \mathrm{Ni}$, $\mathrm{Zn}, \mathrm{Cd}$ and $\mathrm{Hg}$ via the soil media was enhanced with increasing soil depth profile, may be due to less binding with the organic compounds. The whole As exists in the toxic inorganic forms i.e. As(III) and $\mathrm{As}(\mathrm{V})$ in the geomedia.

\section{ACKNOWLEDGEMENTS}

We are thankful to the UGC, New Delhi for awarding BSR grant to KSP.

\section{REFERENCES}

Agrawal, P., Mittal, A., Prakash, R., Kumar, M., Singh, T.B. \& Tripathi, S.K. 2010. Assessment of contamination of soil due to heavy metals around coal fired thermal power plants at Singrauli region of India. Bull. Environ. Contam. Toxicol. 85(2): 219-223.

Bhuiyan, M.A.H., Parvez, L., Islam, M.A., Dampare, S.B. \& Suzuki, S. 2010. Heavy metal pollution of coal mine-affected agricultural soils in the northern part of Bangladesh. J. Hazard. Mater. 173(1-3): 384-392.

Chou, C.L. 2012. Sulfur in coals: a review of geochemistry and origins. Int. J. Coal Geol. 100(10): 1-13.

Dahal, B.M., Fuerhacker, M., Mentler, A., Karki, K.B., Shrestha, R.R. \& Blum, W.E.H. 2008. Arsenic contamination of soils and agricultural plants through irrigation water in Nepal. Environ. Pollut. 155(1): 57-163.

Guttikunda, S.K. \& Jawahar, P. 2014. Atmospheric emissions and pollution from the coal-fired thermal power plants in India. Atmos. Environ. 92: 449-460.

Han, Y.M., Cao, J.J., Chow, J.C., Watson, J.G., An, Z.S. \& Liu, S.X. 2009. Elemental carbon in urban soils and road dusts in Xi'an, China and its implication for air pollution. Atmos. Environ. 43(15): 2464-2470.

He, Y. \& Zhang, G.L. 2009. Historical record of black carbon in urban soils and its environmental implications. Environ. Pollut. 157(10): 2684-2688.
Ilwon, K., Joo, S.A., Young, S.P. \& Kyoung-Woong, K. 2003. Arsenic contamination of soils and sediments from tailings in the vicinity of Myungbong Au mine, Korea. Chem. Spec. Bioavailab. 15(3): 67-74.

Kwon, J.C., Nejad, Z.D. \& Jung, M.C. 2017. Arsenic and heavy metals in paddy soil and polished rice contaminated by mining activities in Korea. Catena 148: 92-100.

Li, X., Liu, L., Wang, Y., Luo, G., Chen, X., Yang, X., Gao, B. \& He, X. 2012. Integrated assessment of heavy metal contamination in sediments from a coastal industrial basin, NE China. PLOS One 7(6): e39690.

Muller, G. 1969. Index of geo-accumulation in sediments of the Rhine River. Geo. J. 2(3): 108-118.

Muri, G., Cermelj, B., Faganeli, J. \& Brancelj, A. 2002. Black carbon in Slovenian alpine lacustrine sediments. Chemosphere 46(8): 1225-1234.

Obaidy, A.H.M.J.Al. \& Mashhadi, A.A.M.Al. 2013. Heavy metal contaminations in urban soil within Baghdad city, Iraq. J. Environ. Protec. 4(1): 72-82.

Pandey, V.C., Singh, J.S., Singh, R.P., Singh, N. \& Yunus, M. 2011. Arsenic hazards in coal ?y ash and its fate in Indian scenario. Resour. Conserv. Recyl. 55(9): 819-835.

Patel, K.S., Shukla, A., Tripathi, A.N. \& Hoffmann, P. 2001. Heavy metal concentrations of precipitation in east Madhya Pradesh of India. Water Air Soil Pollut. 130(1-4): 463-468.

Patel, K.S., Yadav, A., Rajhans, K., Ramteke, S., Sharma, R., Wysocka, I. \& Jaron, I. 2016. Exposure of fluoride in coal basin. Int. J. Clean Coal Energy 5(1): 1-12.

Plyaskina, O.V. \& Ladonin, D.V. 2009. Heavy metal pollution of urban soils. Eura. Soil Sci. 42(7): 816-823.

Rudnick, R.L. \& Gao, S. 2003. Composition of the continental crust. In 'The Crust' (Rudnick, R. L., ed) Treatise on Geochemistry, (Holland, H.D. and Turekian, K.K., eds), Elsevier- Pergamon, Oxford, pp. 1-64.

Sengupta, S., Chatterjee, T., Ghosh, P.B. \& Saha, T. 2010. Heavy metal accumulation in agricultural soils around a coal fired thermal power plant (Farakka) in India. $J$. Environ. Sci. Eng. 52(4): 299-306.

Sheela, A.M., Letha, J., Joseph, S. \& Thomas, J. 2012. Assessment of heavy metal contamination in coastal lake sediments associated with urbanization: Southern Kerala, India. Lakes Reserv. Res. Manag. 17(2): 97-112.

Sheoran, V., Sheoran, A.S. \& Tholia, N.K. 2011. Acid mine drainage: an overview of Indian mining industry. Int. $J$. Earth Sci. Eng. 4(6): 1075-1086.

Shrivastava, A., Barla, A., Yadav, H. \& Bose, S. 2014. Arsenic contamination in shallow groundwater and agricultural soil of Chakdaha block, West Bengal, India. Front. Environ. Sci. 2: 1-9.

Sinex, S.A. \& Helz, G.R. 1981. Regional geochemistry of trace elements in Chesapeake Bay sediments. Environ. Geol. 3(6): 315-323.

Singh, R., Singh, D.P., Kumar, N., Bhargava, S.K. \& Barman, S.C. 2010. Accumulation and translocation of heavy metals in soil and plants from fly ash contaminated area. $J$. Environ. Bio. 31(4): 421-430.

Tan, K.H. 2005. Soil Sampling, Preparation and Analysis. 2nd ed., CRC Press, Boca Raton, FL.

Tomlinson, D.L., Wilson, J.G., Harris, C.R. \& Jeffrey, D.W. 1980. Problem in assessment of heavy-metal levels in estuaries and the formation of a pollution index. Helgoländer Meeres. 33(1-4): 566-575.

Whitmore, T.J., Riedinger-Whitmore, M.A., Smoak, J.M., Kolasa, K.V., Goddard, E.A. \& Bindler, R. 2008. Arsenic contamination of lake sediments in Florida: evidence of herbicide mobility from watershed soils. J. Paleolimnol. 40(3): 869-884. 